\title{
Evaluation of Perna perna (Linné, 1758) as a Tool to Monitoring Trace Metals Contamination in Estuarine and Coastal Waters of Rio de Janeiro, Brazil
}

\author{
Eleine Francioni ${ }^{a}$, Angela de L. Rebello Wagener ${ }^{*, a}$, Reinaldo de C. Calixto $^{a}$ and Gildo C. Bastos ${ }^{b}$ \\ ${ }^{a}$ Departamento de Química, Pontifícia Universidade Católica do Rio de Janeiro, 22453-900 Rio de Janeiro-RJ, Brazil \\ ${ }^{b}$ Departamento de Meio Ambiente, FURNAS, 22283-900 Rio de Janeiro-RJ, Brazil
}

\begin{abstract}
Foram coletados espécimes de mexilhões Perna perna de diversas estações ao longo da costa do Rio de Janeiro e analisados os conteúdos de cobre, zinco, cádmio e cromo. Apesar da grande variabilidade nos organismos pertencentes à mesma população, a avaliação estatística permitiu a diferenciação através de níveis de metal traço entre regiões e estações de coleta assim como entre machos e fêmeas. Diferenças nos conteúdos de metais não confirmam as espectativas baseadas em fontes de contaminação e dados existentes da concentração nas águas.
\end{abstract}

Perna perna was collected from several sites along the coast of Rio de Janeiro and analysed for the content of copper, zinc, cadmium and chromium. In spite of the observed concentration variability in organisms pertaining to the same population, statistical evaluation allowed metal level differentiation among regions and sites as well as between males and females. Differences in metal contents did not confirm expectations based on source strength and existing data on water concentration.

Keywords: trace metals, Perna perna, tropical waters, Guanabara Bay

\section{Introduction}

Monitoring contamination in the marine environment by means of chemical analysis of a certain substance in water or sediments is a tedious and expensive procedure. The use in pollution monitoring of certain sedentary organisms (bioindicators) which accumulate contaminants from the surrounding seawater and are resistant to a wide range of contaminant concentration has been considered an advantageous alternative. ${ }^{1,2}$

There are, however, strong evidences that a simple relation between trace metal levels in the environment and in the tissue of organisms does not exist. Depledge and Rainbow consider that understanding a particular metal load in a bioindicator organism requires consideration of its physiological status. ${ }^{3}$ In addition, the final concentration in a certain organ or in the whole organism depends on the metal speciation and on properties of the environment.

There is a number of abiotic and biotic factors which are still to be fully understood, that can influence the final metal concentration observed in a certain organism, ${ }^{4,5}$ in mussels and other invertebrates, ${ }^{6,7}$ the combination of these factors leads to a high metal content variability among

* e-mail: angela@rdc.puc-rio.br organisms of the same population. ${ }^{1}$ The fact that different specimens react differently when exposed to the same metal concentration presents from one side advantages for pollution studies, but also poses limits to the use in monitoring and requires establishment of specific optimisation methods. ${ }^{8,9}$

Although several reports are available which discuss the use of bioindicators as well as the factors that may control accumulation of trace metals in marine organisms, relatively few such studies have been conducted in tropical areas. Most of these studies have used homogenated samples, excluding information about relationship between contaminant burdens and individual characteristics. ${ }^{10-12}$ Other deficiences include genotypically or phenotypically determinated, interpopulation differences in susceptibility to trace metals, related to differences in climate or the inherent sensivity of species occupying different geographic regions. ${ }^{13}$

In Brazil were the first to use the mussel Perna perna as a bioindicator for cadmium and lead contamination in Guanabara Bay. ${ }^{14} \mathrm{Few}$ other studies have been carried out in the country using Perna perna and Crassostrea brasiliana, but little has been concluded on how reliably these organisms are recording the environmental contamination. ${ }^{14-18}$ 
P. perna is a bivalve present over a large extension of the Brazilian coast that has, principally, all desirable properties to a potential bioindicator. ${ }^{1,19}$ It can also be found in other coastal areas of South America, Africa and in the western Mediterranean. In the tropics, this species releases gamets over the whole year although the release occurs more intensively during Spring and Autumm. Sexual maturity initiates when the organism reaches $26-29 \mathrm{~mm}$. Both the biology and ecology of the species is well documented. ${ }^{14-20}$

The wide geographic distribution of $P$. perna makes the species a good candidate for the establishment of biomonitoring procedures in tropical areas where countries are least prepared economically and technically to address the issue through more sophisticated chemical analysis. Having this in mind, the objective of the present work was to investigate $\mathrm{Cu}, \mathrm{Cr}, \mathrm{Zn}$ and $\mathrm{Cd}$ contamination in several sites along the coast of Rio de Janeiro and, by means of statistical instruments, to examine how well the concentration record in $P$. perna matches site specific properties and existing information on contamination sources.

\section{Materials and Methods}

\section{Sampling and site description}

Ten specimens were collected either by diving or directly from the rocky substrate in the period between December, 1996 and January, 1997 at each of the 18 sampling stations (Figure1) contained within 6 regions of Rio de Janeiro coast.

The region of Arraial do Cabo (station 1 to 3 ) is rather pristine but is subjected to seasonal upwelling in the period from October to March that brings cold waters enriched in copper and other trace metals..$^{21,22}$

Sepetiba Bay (stations 15 and 16) is contaminated by releases of cadmium and zinc from a metallurgic industries and in lesser degree by sewage and oil, while Guanabara Bay (stations 06 to 10) receives heavy loads of a diversity of organic and inorganic contaminants. According to Rebello et al. chromium, zinc and copper are the most relevant amongst trace metal contaminants in Guanabara Bay. ${ }^{23}$ The bay is highly eutrophic with an average net primary production of $2 \mathrm{~g} \mathrm{~m}^{-2} \mathrm{day}^{-1}$. Historically, Guanabara and Sepetiba Bays were important sources of fisheries and served as nursery and reproduction sites for a number of species before being seriously altered by the introduction of sewage, industrial wastes and litter as well as by overfishing. In what pollution is concerned Guanabara Bay has remained in a steady condition over the last 15 years, because abatement actions have not been implemented and also due to the economic stagnation in the region. In Sepetiba Bay, environmental conditions are critical due to population increase in the basin unattended by sewage treatment system, increase in ship traffic serving a new harbour that handles iron ore exportation and an up-scaled oil terminal.

The oceanic beaches of Rio de Janeiro city (stations 11 to 14) are contaminated by domestic effluents and urban drainage waters while the oceanic beaches of Niteroi (stations 4 and 5) are affected by materials leaving Guanabara Bay during low tidal periods. Stations 17 and 18 are located in mussel farming areas of Ilha Grande Bay. This bay should be principally pristine although it may suffer influence from the nearby Sepetiba Bay.

\section{Analytical methodologies}

Mussel shells were cleaned "in situ" and washed with local seawater before storage at $4{ }^{\circ} \mathrm{C}$ in clean polyethylene bags for transportation to the laboratory. Once in the laboratory, shell and soft parts length were measured and fresh weight was obtained after absorbing the excess of water by lying the organism upon a clean sheet of ash free filter paper over $15 \mathrm{~min}$. Single mussels were then placed in pre-cleaned polypropylene centrifuge tubes, previously tested for metal contamination, and stored at $-18{ }^{\circ} \mathrm{C}$. Dry weight was determined in a separate group of 10 organisms after drying to constant weight at $110^{\circ} \mathrm{C}$. In order to avoid possible size specific effects, preference was given to collect at each site organisms of similar size.

All materials used for storage and manipulation or in the analytical procedures were carefully cleaned with Detertec $^{\circledR}$ (Vetec) $2 \%$ followed by immersion in $20 \%$ nitric acid Merck p.a. over one week and rinsing with Milli-Q water.

Sample digestion was carried out directly in the centrifuge tubes inserted in cavities of an alumminum block specially designed to fit a large number of tubes. According to the optimised procedure, $15 \mathrm{~mL}$ of SupraPur Merck or distilled concentrated nitric acid were added to each tube thereafter kept at $85-90{ }^{\circ} \mathrm{C}$ over $24 \mathrm{~h}$. Digestion was completed with the addition of $10 \mathrm{~mL}$ of $\mathrm{H}_{2} \mathrm{O}_{2}$ Merck p.a. and heating at $80^{\circ} \mathrm{C}$ over 5 hours. Digestion batches of 30 samples each included three blanks and two control samples (reference material IAEA MA-M-2/TM and ROPME).

Copper and chromium were determined by GFAAS and zinc by FAAS using a 1100 Perkin Elmer spectrometer equipped with a deuterium corrector. Cadmium was determined using an Elan 5000 Perkin Elmer ICP-MS, for Calcium analysis were conducted in a Perkin Elmer P1000 


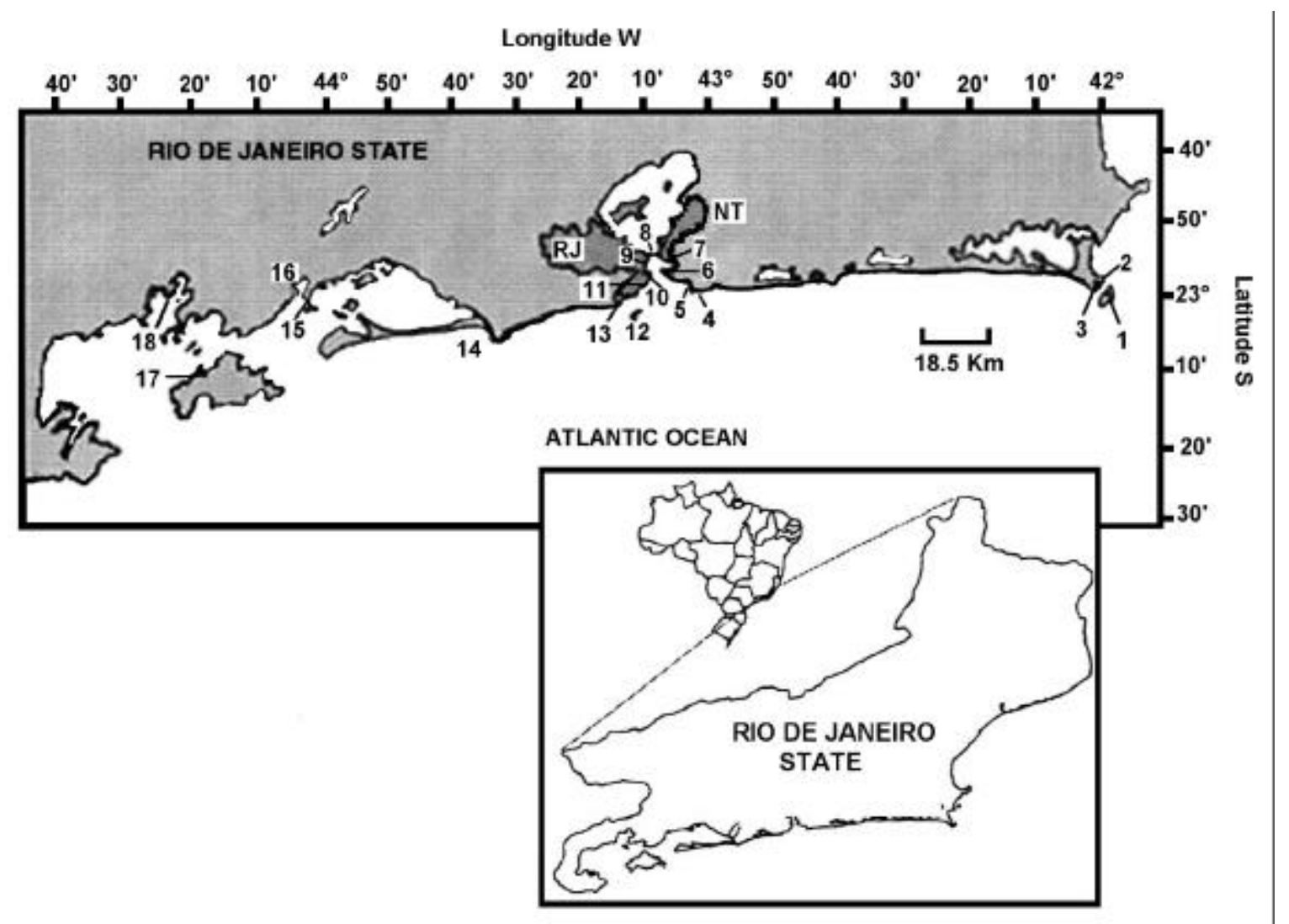

Figure 1. Sampling sites along Rio de Janeiro coast. Stations: 1. Cabo Frio Island; 2. Beach of Angels; 3. Prainha; 4. Itaipu; 5. Piratininga; 6. Santa Cruz Fortress, 7. Boa Viagem Island; 8. Rio-Niterói Bridge; 9. Marina da Glória; 10. Vermelha Beach; 11. Copacabana Fortress; 12. Cagarras Islands; 13. Vidigal Beach; 14. Barra de Guaratiba; 15. Guaíba Island; 16. Ponta da Cruz; 17. Grande Island; 18. IAJA.

ICP-AES. Detection limit for $\mathrm{Cd}, \mathrm{Cu}, \mathrm{Zn}, \mathrm{Cr}$ and $\mathrm{Ca}$ in the real samples were $0.7 \mu \mathrm{g} \mathrm{L}^{-1}\left(\mathrm{sd}=0.07 \mu \mathrm{g} \mathrm{L}^{-1}\right), 0.71 \mu \mathrm{g} \mathrm{L}^{-1}$ $\left(\mathrm{sd}=0.002 \mu \mathrm{g} \mathrm{L}{ }^{-1}\right), 0.016 \mathrm{mg} . \mathrm{L}^{-1}\left(0.001 \mathrm{mg} \mathrm{L}^{-1}\right), 0.15 \mu \mathrm{g} \mathrm{L}-1$ $\left(\mathrm{sd}=0.006 \mu \mathrm{g} \mathrm{L}^{-1}\right)$, and $0.002 \mathrm{mg} \mathrm{L}^{-1}\left(\mathrm{sd}=0.0013 \mathrm{mg} \mathrm{L}^{-1}\right)$ respectively. Optimisation of the analytical protocol and quality assurance tests were carried out using the following reference materials of fish tissues from International Atomic Energy Agency: IAEA MA-A-2/TM and ROPME. The analytical results for the reference materials can be seen in Table 1.

Temperature and $\mathrm{pH}$ were measured "in situ" respectively with mercury thermometer and pHmeter B $378 \mathrm{Micronal}^{\circledR}$, using buffer solutions of Merck for calibration. Particulate matter content was obtained through Millipore ${ }^{\circledast}$ filtration apparatus and salinity was measured in laboratory using a conductimeter LF 92 Wissenschaftlich Technische Werkstäten ${ }^{\circledR}$ from seawater samples of each station.

\section{Results and Discussion}

Concentration range and averages, reported in wet weight basis, and other relevant data are shown in Table 2 and 3. Similarly to the results reported by Heizen and Rebello, ${ }^{13}$ percentage of water was on the average $81.4 \%$ $\pm 1.3 \%$.

We applied the Shapiro-Wilk test to verify the normality of data distribution, first using the entire collection of data

Table 1. Analytical results for the reference materials IAEA MA-A-2/TM and MA-ROPME -1

\begin{tabular}{lccccccc}
\hline & \multicolumn{2}{c}{ Cd } & \multicolumn{2}{c}{ Cu } & \multicolumn{2}{c}{ Zn } & \multicolumn{2}{c}{ Rr } \\
& MA-A-2/TM & ROPME & MA-A-2/TM & ROPME & MA-A-2/TM & ROPME & MA-A-2/TM \\
\hline $\begin{array}{l}\text { Found values } \\
\text { (mean } \pm \text { sd, n=3-7) }\end{array}$ & $0.068 \pm 0.001$ & $0.0043 \pm 0.0021$ & $4.00 \pm 0.10$ & $0.68 \pm 0.17$ & $32 \pm 2.14$ & $17.64 \pm 1.71$ & $0.27 \pm 0.09$ \\
Certified values & $0.062-0.070$ & $0.003-0.027$ & $3.9-4.1$ & $0.50-0.74$ & $32-34.00$ & $16.32-17.28$ & $0.14-0.41$ \\
\hline
\end{tabular}

sd: standard desviation. 
and then grouping data according to the sampling site and to the region. The distribution of the entire collection of data for each metal was not normal, however, in some regions and in most sites data was normally distributed.

Table 2. Temperature, salinity, $\mathrm{pH}$ and particulate matter (December, 1996 and January, 1997). Stations:1. Cabo Frio Island; 2. Beach of Angels; 3. Prainha; 4. Itaipu; 5. Piratininga; 6. Santa Cruz Fortress; 7. Boa Viagem Island; 8. Rio-Niterói Bridge; 9. Marina da Glória; 10. Vermelha Beach; 11. Copacabana Fortress; 12. Cagarras Islands; 13. Vidigal Beach; 14. Barra de Guaratiba; 15. Guaíba Island; 16 Ponta da Cruz; 17. Grande Island; 18. IAJA

\begin{tabular}{clccc}
\hline Station & $\begin{array}{c}\text { Temp. } \\
\left({ }^{\circ} \mathrm{C}\right)\end{array}$ & Salinity & $\mathrm{pH}$ & $\begin{array}{c}\text { Part. Matter } \\
(\mathrm{mg} / \mathrm{L})\end{array}$ \\
\hline 1 & 24.5 & 35.5 & 8.53 & 7.9 \\
2 & 26 & 35.1 & 8.05 & 11.5 \\
3 & 26.5 & 35.8 & - & 9.8 \\
4 & 21 & 33.6 & 8.34 & 4.7 \\
5 & 21 & 33.9 & 8.30 & 2.7 \\
6 & 24 & 29.4 & 8.73 & 35.9 \\
7 & 22 & 31.3 & - & 33.8 \\
8 & 26 & 28.6 & 8.7 & 25.7 \\
9 & 23 & 31.5 & 8.69 & 33.7 \\
10 & 17 & 34.9 & 9.3 & 23.5 \\
11 & 21 & 34.4 & 8.01 & 14.1 \\
12 & 20 & 34.7 & 8.36 & 15.3 \\
13 & 24 & 33.5 & 8.07 & 14.5 \\
14 & 23.5 & 32.4 & - & 11.4 \\
15 & 24 & 33.3 & 8.01 & 13.2 \\
16 & 25 & 32.7 & - & 10.7 \\
17 & 25 & 33.7 & 8.52 & 11.1 \\
18 & 26 & 31.8 & 8.10 & 10.7 \\
\hline
\end{tabular}

The application of the Duncan and the Kruskal-Wallis tests to data grouped according to sex, region or site gave very similar results, nonetheless the data presentation in the former test allows easier observation of conclusions as can be seen in Table 4 and 5. Despite the large data variability, the statistical tests revealed significant differences among sites and regions. In Table 4 and 5, that shows the results of the Duncan test for $\mathrm{Zn}, \mathrm{Cr}, \mathrm{Cu}$, and $\mathrm{Cd}$, horizontal bars are linking regions and sites of similar concentrations.

As reported for genera Mytillus sp. metal content in $P$. perna tissue showed a high intra-population variability. ${ }^{1,8}$ In all sites we verified that sampled organisms were subjected to different physiological condition and reproductive cycle stage, as for example stages of spawning and redevelopment. These biotic differences although affecting the levels of trace metal in tissues, are unavoidable in a sampling program because they represent a typical feature of P. perna populations all over the year in the sampled area. ${ }^{24,25}$ The relative standard deviation from the mean concentration in each site provides a good estimate of the intra-population variability. The range of the calculated values, $06-66 \%$ for $\mathrm{Ca}, 14-31 \%$ for $\mathrm{Cu}, 12-$ $43 \%$ for $\mathrm{Zn}, 20-52 \%$ for $\mathrm{Cr}$, and $14-34 \%$ for $\mathrm{Cd}$, were independent of the concentration level, however, for chromium wider variability occurred in populations from regions where metal contamination has been proved (Guanabara Bay: 31-52\% and Rio beaches: $36-47 \%$ ).

Table 3. Mean, minimum and maximum shell size $(\mathrm{cm})$, wet weight $(\mathrm{g})$ and concentrations of $\mathrm{Cd}, \mathrm{Cu}, \mathrm{Cr}, \mathrm{Ca}$ and $\mathrm{Zn}$ in $\mathrm{mg} \mathrm{g}^{-1}$ w.w. from each station (December, 1996 and January, 1997). Stations:1. Cabo Frio Island; 2. Beach of Angels; 3. Prainha; 4. Itaipu; 5. Piratininga; 6. Santa Cruz Fortress; 7. Boa Viagem Island; 8. Rio-Niterói Bridge; 9. Marina da Glória; 10. Vermelha Beach; 11. Copacabana Fortress; 12. Cagarras Islands; 13. Vidigal Beach; 14. Barra de Guaratiba; 15. Guaíba Island; 16. Ponta da Cruz; 17. Grande Island; 18. IAJA

\begin{tabular}{|c|c|c|c|c|c|c|c|}
\hline Station & Shell size & Wet weight & $\mathrm{Cd}$ & $\mathrm{Cu}$ & $\mathrm{Cr}$ & $\mathrm{Ca}$ & $\mathrm{Zn}$ \\
\hline 1 & $6.31(5.27-7.28)$ & $5.83(3.98-8.11)$ & $0.20(0.14-0.22)$ & $1.16(0.86-1.4)$ & $0.10(0.06-0.16)$ & $739(468-1423)$ & $22.05(11-94-37.37)$ \\
\hline 2 & $6.10(5.14-6.81)$ & $5.45(3.58-7.45)$ & $0.07(0.05-0.09)$ & $1.39(1.1-1.6)$ & $0.08(0.05-0.13)$ & $597(449-985)$ & $26.69(21.35-39.11)$ \\
\hline 3 & $5.89(5.48-6.55)$ & $4.53(3.47-6.71)$ & $0.10(0.08-0.14)$ & $1.05(0.66-1.8)$ & $0.11(0.08-0.17)$ & $834(555-1511)$ & $26.03(6.95-38.07)$ \\
\hline 4 & $6.46(6.00-7.60)$ & $4.67(3.09-6.62)$ & $0.08(0.06-0.10)$ & $1.51(1.1-2.1)$ & $0.07(0.04-0.10)$ & $379(232-599)$ & $29.82(17.23-49.56)$ \\
\hline 5 & $5.33(5.10-5.48)$ & $2.55(2.10-3.42)$ & $0.09(0.06-0.13)$ & $1.48(1.05-1.9)$ & $0.12(0.06-0.22)$ & $455(351-638)$ & $34.42(20.65-50.49)$ \\
\hline 6 & $6.99(6.22-7.78)$ & $7.16(4.08-9.40)$ & $0.05(0.04-0.07)$ & $1.62(1.1-2.2)$ & $0.05(0.03-0.10)$ & $387(339-473)$ & $48.27(30.97-59.23)$ \\
\hline 7 & $6.56(5.85-6.94)$ & $7.29(5.13-9.28)$ & $0.03(0.02-0.04)$ & $1.13(0.08-1.4)$ & $0.05(0.03-0.07)$ & $470(435-534)$ & $32.43(17.81-49.33)$ \\
\hline 8 & $6.37(6.09-6.75)$ & $6.80(4.49-11.00)$ & $0.04(0.02-0.08)$ & $1.96(1.6-2.3)$ & $0.08(0.04-0.11)$ & $427(372-535)$ & $41.95(25.79-61.42)$ \\
\hline 9 & $6.88(6.24-7.58)$ & $7.51(5.03-9.39)$ & $0.03(0.02-0.04)$ & $1.80(1.4-2.5)$ & $0.10(0.03-0.20)$ & $583(455-833)$ & $31.95(26.68-37.05)$ \\
\hline 10 & $6.31(5.26-7.35)$ & $5.27(3.66-8.82)$ & $0.07(0.05-0.10)$ & $2.05(1.4-2.4)$ & $0.16(0.08-0.26)$ & $750(395-1898$ & $30.49(20.81-40.52)$ \\
\hline 11 & $6.49(6.10-6.99)$ & $5.13(3.22-6.76)$ & $0.07(0.05-0.10)$ & $1.47(0.71-1.91)$ & $0.08(0.04-0.13)$ & $472(350-712)$ & $29.90(21.82-38.47)$ \\
\hline 12 & $5.52(5.18-6.12)$ & $4.27(3.07-6.16)$ & $0.10(0.07-0.14)$ & $1.46(0.94-2.34)$ & $0.05(0.02-0.11)$ & 497 (424-602) & $34.27(20.39-51.57)$ \\
\hline 13 & $5.59(5.31-5.93)$ & $3.64(2.20-4.72)$ & $0.08(0.06-0.15)$ & $2.28(1.7-2.8)$ & $0.17(0.10-0.28)$ & $531(425-614)$ & $34.06(21.85-47.03)$ \\
\hline 14 & $4.78(4.51-5.17)$ & $2.78(2.44-3.69)$ & $0.06(0.04-0.08)$ & $1.27(0.79-1.71)$ & $0.14(0.08-0.20)$ & $450(343-650)$ & $34.40(23.52-43.38)$ \\
\hline 15 & $5.68(5.08-6.50)$ & $5.55(3.69-7.84)$ & $0.06(0.04-0.08)$ & $1.19(0.76-1.9)$ & $0.05(0.03-0.08)$ & $516(395-716)$ & $37.52(18.94-68.91)$ \\
\hline 16 & $5.41(5.00-6.20)$ & $3.91(3.28-4.48)$ & $0.06(0.05-0.08)$ & $1.15(0.71-1.7)$ & $0.08(0.04-0.13)$ & $567(448-697)$ & $42.75(23.83-67.74)$ \\
\hline 17 & $6.93(6.43-7.93)$ & $4.83(3.51-6.30)$ & $0.13(0.10-0.16)$ & $1.12(0.81-1.5)$ & $0.07(0.05-0.13)$ & $547(362-1569)$ & $30.03(16.2-37.95)$ \\
\hline 18 & $6.97(5.83-7.45)$ & $5.46(4.06-6.97)$ & $0.21(0.15-0.25)$ & $1.15(0.91-1.5)$ & $0.12(0.08-0.25)$ & $495(299-1158)$ & $27.42(19.96-40.73)$ \\
\hline $\begin{array}{c}\text { Limited conc. } \\
\text { in Fisheries }\end{array}$ & - & - & 1.00 & 30.00 & 0.10 & - & 50.00 \\
\hline
\end{tabular}


Table 4. Results for Duncan's test for $\mathrm{Cd}, \mathrm{Cu}$ and $\mathrm{Zn}$ bioacumulated in P. perna from different regions sampled along Rio de Janeiro State coast. $\mathrm{AC}=$ Arraial do Cabo, $\mathrm{ORJ}=$ Oceanic beaches of Rio de Janeiro City, ONT $=$ Oceanic beaches of Niterói, GB= Guanabara Bay, $\mathrm{SB}=$ Sepetiba Bay, $\mathrm{IGB}=$ Grande Island Bay. Mean concentratrion in $\mathrm{mg} \mathrm{g}^{-1} \mathrm{ww}$. Mean concentrations in boxes not significantly different

\begin{tabular}{lcccccc}
\hline Trace Metal & \multicolumn{6}{c}{ Regions } \\
\hline Cadmium & GB & BS & ORJ & ONT & AC & \multicolumn{1}{c}{ IGB } \\
Mean & (0.043) & $(0.056)$ & $(0.077)$ & $(0.083)$ & $(0.120)$ & $(0.163)$ \\
\cline { 3 - 7 } & & & & & & \\
Mepper & IGB & BS & AC & ONT & ORJ & GB \\
Mean & $(1.11)$ & $(1.14)$ & $(1.19)$ & $(1.48)$ & $(1.59)$ & $(1.72)$ \\
Zinc & & & & & & \\
Mean & AC & IGB & ORJ & ONT & GB & SB \\
\hline & $(24.72)$ & $(28.52)$ & $(32.85)$ & $(35.42)$ & $(37.10)$ & $(39.14)$ \\
\hline
\end{tabular}

In general, trace metal levels were low with exception of chromium that in certain sites of all regions presented values exceeding the recommended value for human consumption (Brazilian legislation gives $0.1 \mathrm{mg} \mathrm{Cr} \mathrm{g}^{-1}$ wet weight basis as maximum allowance).

Despite the large data variability, the statistical tests revealed significant differences among sites and regions. In Table 4 and 5, that shows the results of the Duncan test for $\mathrm{Zn}, \mathrm{Cr}, \mathrm{Cu}$ and $\mathrm{Cd}$, horizontal bars are linking regions and sites of similar concentrations.

For zinc, four regions are statistically grouped under the same category (average values between 32 and $39 \mu \mathrm{g} \mathrm{g}^{-1}$ ) but only in Guanabara Bay and Sepetiba Bay the sources of $\mathrm{Zn}$ are well known and documented. ${ }^{13,23,25-27}$ In Santa Cruz Fortress, Guanabara Bay, 50\% of the sampled organisms presented $\mathrm{Zn}$ concentrations that were above the Brazilian maximum permissible level for food (50 $\mu \mathrm{g}$ $\mathrm{Zn}^{-1}$ ), while in other sites in both bays only two or three of the sampled organisms had values above this limit.

In the case of cadmium, populations from Sepetiba Bay (stations 15 and 16) and Barra de Guaratiba (station 14) should show higher metal loads, based on the presence of a major source of cadmium in the northeastern part of the bay and on previous reports of Cd levels $\left(1.6 \mu \mathrm{g} \mathrm{Cd} \mathrm{g}^{-1} \mathrm{dw}\right)$ in Crassostrea brasiliana from Barra de Guaratiba. Contrary to this expectation, cadmium concentrations were highest in the two presumably least contaminated regions (Grande Island and Arraial do Cabo). ${ }^{14} \mathrm{We}$ assume that upwelling waters in Arraial do Cabo are responsible for the observed levels, although the process of upwelling in the region is rather discontinuous. Wagener ${ }^{22}$ reported $\mathrm{Cd}$ values for these waters $\left(0.30 \mathrm{nmol} \mathrm{Kg}^{-1}\right)$ that are indeed 5 times higher than in the warmer water masses reaching
Table 5. Results for Duncan's test for $\mathrm{Cd}, \mathrm{Cr}, \mathrm{Cu}$ and $\mathrm{Zn}$ bioacumulated in P. perna from different sites sampled along Rio de Janeiro State coast. $\mathrm{AC}=$ Arraial do Cabo, ORJ= Oceanic beaches of Rio de Janeiro City, ONT= Oceanic beaches of Niterói, GB= Guanabara Bay, $\mathrm{SB}=$ Sepetiba Bay, $\mathrm{IGB}=$ Grande Island Bay. Mean concentratrion in $\mu \mathrm{g} \mathrm{g}^{-1}$ ww. Mean concentrations in boxes not significantly different. St $1=$ Cabo Frio Island, St $2=$ Beach os Angels, St $3=$ Prainha, St $4=$ Itaipu, St $5=$ Piratininga, St $6=$ Sta Cruz Fortress, St 7 = Boa Viagem, St $8=$ Rio-Niterói Bridge, St $9=$ Marina da Glória, St $10=$ Vermelha Beach, St $11=$ Copacabana Fortress, St $12=$ Cagarras Islands, St $13=$ Vidigal Beach, St $14=$ Barra de Guaratiba, St $15=$ Guaíba Island, St $16=$ Ponta da Cruz, St $17=$ Grande Island Bay, St $18=$ IAJA

\begin{tabular}{|c|c|c|c|c|c|}
\hline \multicolumn{6}{|c|}{ Cadmium } \\
\hline $\mathbf{A C}$ & St 2 & \multirow[b]{3}{*}{ St 9} & St 3 & \multicolumn{2}{|r|}{ St 1} \\
\hline Mean & \begin{tabular}{|l|}
0.066 \\
\end{tabular} & & 0.103 & \multirow[b]{2}{*}{ St 6} & \begin{tabular}{|l|}
0.194 \\
\end{tabular} \\
\hline GB & St 7 & & St 8 & & St10 \\
\hline Mean & \begin{tabular}{|l|}
0.024 \\
\end{tabular} & 0.026 & \begin{tabular}{|l|}
0.041 \\
\end{tabular} & \begin{tabular}{|l|}
0.054 \\
\end{tabular} & 0.064 \\
\hline ORJ & St 14 & St 11 & St 13 & St 12 & \\
\hline Mean & 0.058 & 0.072 & \begin{tabular}{|l|}
0.081 \\
\end{tabular} & 0.097 & \\
\hline IGB & St 17 & \multicolumn{3}{|l|}{ St 18} & \\
\hline Mean & 0.123 & \multicolumn{3}{|l|}{0.205} & \\
\hline \multicolumn{6}{|c|}{ Copper } \\
\hline $\mathrm{AC}$ & St 3 & St 1 & \multirow[b]{3}{*}{ St 9} & St 2 & \multirow[b]{3}{*}{ St 10} \\
\hline Mean & 1.04 & 1.09 & & 1.38 & \\
\hline GB & St 7 & St 6 & & St 8 & \\
\hline Mean & 1.11 & 1.70 & 1.81 & 1.96 & 2.07 \\
\hline ORJ & St 14 & St 12 & St 11 & St 13 & \\
\hline Mean & 1.22 & 1.46 & 1.5 & 2.22 & \\
\hline \multicolumn{6}{|c|}{ Chromium } \\
\hline $\mathbf{A C}$ & St 2 & \multicolumn{2}{|c|}{ St 1} & 3 & \\
\hline Mean & 0.082 & \multicolumn{3}{|c|}{$\begin{array}{|ll|}0.108 & 0.114 \\
\end{array}$} & \\
\hline ONT & St 4 & \multicolumn{2}{|c|}{ St 5} & & \\
\hline Mean & \begin{tabular}{|l|}
0.069 \\
\end{tabular} & \multicolumn{2}{|c|}{0.115} & & \\
\hline GB & St 7 & St 6 & St 8 & St 9 & St 10 \\
\hline Mean & 0.051 & 0.056 & 0.076 & 0.104 & \begin{tabular}{|l|}
0.160 \\
\end{tabular} \\
\hline ORJ & St 12 & St 11 & St 14 & St 13 & \\
\hline Mean & \begin{tabular}{|l|}
0.050 \\
\end{tabular} & 0.075 & 0.132 & 0.171 & \\
\hline SB & St 15 & St 16 & & & \\
\hline Mean & \begin{tabular}{|l|}
0.049 \\
\end{tabular} & \begin{tabular}{|l|}
0.080 \\
\end{tabular} & & & \\
\hline IGB & St 17 & St 18 & & & \\
\hline Mean & 0.72 & \begin{tabular}{|l|}
0.120 \\
\end{tabular} & & & \\
\hline \multicolumn{6}{|l|}{ Zinc } \\
\hline$\overline{\text { GB }}$ & St 10 & St 7 & St 9 & St 8 & St 6 \\
\hline Mean & 30.92 & 31.03 & 31.46 & 40.12 & 47.73 \\
\hline
\end{tabular}

the western part of Rio de Janeiro coast $\left(0.06 \mathrm{nmol} \mathrm{Kg}{ }^{-1}\right)$. In Grande Island (station 17) high values may derive from material carried out by prevailing currents from the northeastern area of Sepetiba Bay, albeit the main source of $\mathrm{Cd}$ is located further away from this site as compared to 
Table 6. Average concentrations ( $\mathrm{mg} \mathrm{g}^{-1}$ w.w.) of trace metals in males and females and statistical significance of their differences

\begin{tabular}{|c|c|c|c|c|c|c|}
\hline Regions & Sex & Cd & $\mathbf{C r}$ & $\mathrm{Cu}$ & $\mathbf{Z n}$ & $\mathbf{N}$ \\
\hline \multirow[t]{2}{*}{ Total } & Males & $0.0848^{\mathrm{a}}$ & $0.0855 \mathrm{~ns}$ & $1.27^{\mathrm{b}}$ & $30.16^{\mathrm{b}}$ & 78 \\
\hline & Females & $0.0959^{\mathrm{a}}$ & $0.0956 \mathrm{~ns}$ & $1.47^{\mathrm{b}}$ & $35.76^{\mathrm{b}}$ & 100 \\
\hline \multirow[t]{2}{*}{ Arraial do Cabo } & Males & $0.1166 \mathrm{~ns}$ & $0.1062 \mathrm{~ns}$ & $1.10 \mathrm{~ns}$ & $22.33 \mathrm{~ns}$ & 13 \\
\hline & Females & $0.1257 \mathrm{~ns}$ & $0.0968 \mathrm{~ns}$ & $1.25 \mathrm{~ns}$ & $26.51 \mathrm{~ns}$ & 17 \\
\hline \multirow[t]{2}{*}{ Oceanic Beaches of Niterói } & Males & $0.0862 \mathrm{~ns}$ & $0.0884 \mathrm{~ns}$ & $1.44 \mathrm{~ns}$ & $30.26 \mathrm{~ns}$ & 7 \\
\hline & Females & $0.0796 \mathrm{~ns}$ & $0.0956 \mathrm{~ns}$ & $1.52 \mathrm{~ns}$ & $40.98 \mathrm{~ns}$ & 13 \\
\hline \multirow[t]{2}{*}{ Guanabara Bay } & Males & $0.0391 \mathrm{~ns}$ & $0.0550 \mathrm{~ns}$ & $1.60^{\mathrm{b}}$ & $34.29 \mathrm{~ns}$ & 26 \\
\hline & Females & $0.0452 \mathrm{~ns}$ & $0.0912 \mathrm{~ns}$ & $1.85^{\mathrm{b}}$ & $38.21 \mathrm{~ns}$ & 24 \\
\hline \multirow{2}{*}{ Oceanic Beaches of Rio de Janeiro } & Males & $0.0709^{\mathrm{a}}$ & $0.1005 \mathrm{~ns}$ & $1.42^{\mathrm{b}}$ & $30.12^{\mathrm{a}}$ & 18 \\
\hline & Females & $0.0835^{\mathrm{a}}$ & $0.1137 \mathrm{~ns}$ & $1.78^{\mathrm{b}}$ & $35.78^{\mathrm{a}}$ & 22 \\
\hline \multirow[t]{2}{*}{ Sepetiba Bay } & Males & $0.0538 \mathrm{~ns}$ & $0.0637 \mathrm{~ns}$ & $0.91^{\mathrm{a}}$ & $35.90 \mathrm{~ns}$ & 7 \\
\hline & Females & $0.0647 \mathrm{~ns}$ & $0.0662 \mathrm{~ns}$ & $1.31^{\mathrm{a}}$ & $43.54 \mathrm{~ns}$ & 12 \\
\hline \multirow[t]{2}{*}{ Grande Island Bay } & Males & $0.1528 \mathrm{~ns}$ & $0.0852 \mathrm{~ns}$ & $1.03 \mathrm{~ns}$ & $29.17 \mathrm{~ns}$ & 7 \\
\hline & Females & $0.1759 \mathrm{~ns}$ & $0.1071 \mathrm{~ns}$ & $1.20 \mathrm{~ns}$ & $27.40 \mathrm{~ns}$ & 12 \\
\hline
\end{tabular}

ns: not significant; ${ }^{a} \mathrm{p}>0.05 ;{ }^{\mathrm{b}} \mathrm{p}<0.01 ; \mathrm{N}$ : number of samples.

stations 14, 15 and 16. Station 18, where the largest Cd value was observed, is a site of $P$. perna cultivation. As there are no identified sources of $\mathrm{Cd}$ in the vicinities of this site a possibility arises that either the feed or some of the materials used in the mussel farming are contributing to the observed Cd level. Salinity and particulate matter content, that in the case of cadmium play a more important role in determining bioavailabity than organic ligands, are very similar, for example, in station $15(\mathrm{PM}=13.2 \mathrm{mg}$ $\mathrm{L}^{-1}$, salinity $\left.=33.3\right)$ and $18\left(\mathrm{PM}=10.7 \mathrm{mgL}^{-1}\right.$, salinity $=$ 31.8 ), to explain average concentration differences by a factor of 4 .

Copper greatest loads in mussel were found in sites and regions contaminated by sewage discharge (for example, stations 2, 10 and 13). In Guanabara Bay, discharge of $20 \mathrm{~m}^{3} \mathrm{~s}^{-1}$ of raw sewage and localised industrial inputs are responsible for elevated copper levels in waters and sediments (5 to $20 \mathrm{nmol} \mathrm{L}^{-1}$ in water). ${ }^{23}$ The bioavailability of copper is dramatically reduced in the DOC (11 - $15 \mathrm{mg} \mathrm{L}^{-1}$ ) enriched waters of Guanabara Bay where, on the average, more than $95 \%$ of the total dissolved copper is bound to organic ligands. ${ }^{29}$ Pronounced primary production rates $\left(>2 \mathrm{~g} \mathrm{C} \mathrm{m}^{-2}\right.$ day $\left.^{-1}\right)$ in areas where total copper concentration is maximal and of the order of $10^{-8} \mathrm{~mol} \mathrm{~L}^{-1}$ can only be explained by extensive $(99 \%)$ copper binding to strong ligands..$^{30}$ In the vicinity of station 12 , diffusers of a sewage submarine outfall deliver, on the average, $8 \mathrm{~m}^{3} \mathrm{~s}^{-1}$ of raw sewage. In addition to nutrients, the sewage releases a number of toxic substances, inclusively copper. ${ }^{31}$ Steady state copper concentrations in waters under influence of the outfall are of the order of 3.4 to $4.4 \mathrm{nmol} \mathrm{L}^{-1}$, comparable to those in some sites of Guanabara Bay, in spite of the more efficient water exchange of the open sea area where the outfall is located. There are no significant differences, however, between copper levels in mussels from this station and those from Barra de Guaratiba, a presumably less contaminated site for which there is no information on specific sources or on copper levels in the water.

In five out of the six studied regions we found sites where chromium concentration in P. perna was above the Brazilian maximum permissible level for food $(0.1 \mu \mathrm{g} \mathrm{Cr}$ $\mathrm{g}^{-1}$ w.w.). Chromium is a major industrial contaminant in Guanabara Bay and sources have been identified as well in Sepetiba Bay. ${ }^{16}$ Similarly to copper, higher $\mathrm{Cr}$ values in mussel appear associated to be sites of raw sewage discharge. However, except for Sepetiba Bay, regional concentration averages so far obtained are rather similar ranging from $0.091 \mu \mathrm{g} \mathrm{Cr} \mathrm{g}^{-1}$ to $0.11 \mu \mathrm{g} \mathrm{Cr} \mathrm{g}^{-1}$. By means of these results it is neither possible to discriminate pristine from contaminated regions nor to infer that Guanabara Bay receives heavy loads of chromium derived from chemical and leather industries.

Correlation between $\mathrm{Ca}$ and trace metals is not significant. A fraction of $75 \%$ of all Ca concentrations appears in the range of 10 to $2010^{-6} \mathrm{~mol} \mathrm{~g}^{-1}$ while $18 \%$ is smaller than $1010^{-6} \mathrm{~mol} \mathrm{~g}^{-1}$ and $6 \%$ is larger than $2010^{-6}$ $\mathrm{mol} \mathrm{g}^{-1}$. The relation between $\mathrm{Ca}$ and salinity $(\mathrm{r}=0.614$; $p<0.01)$ does not fully explain the presence of those extreme values, although the largest average values were present in organisms from Arraial do Cabo (salinity range: 35.1 to 35.8). Ca values above and below the above range were also observed in some samples from different sites. The molar ratio of $[\mathrm{Cd}] /[\mathrm{Ca}]$ varied in the range of $1.0810^{-5}$ to $2.3610^{-4}$ and is not correlated to the shell and animal size or mass.

The intentional selection of organisms within a narrow range of size resulted in unfavorable conditions to obtain significant correlation and slopes when searching for relations to metal concentration. 
We tested for correlation among concentration of the various trace metals using the whole set of data and grouping according to the site and, in general, did not find significant regressions, except in a few sites $(\mathrm{Zn}$ and $\mathrm{Cd}$ in stations 6, 7 and 17; $\mathrm{Cu}$ and $\mathrm{Cr}$ in station 17). We were unable to discriminate any special feature at these sites or in the population that could have led to the observed good correlation ( $r>0.7$ and $p<0.01$ or 0.05$)$. It is possible that these correlations do not derive from a causal relation.

The use of the Duncan test to discriminate concentration levels in males and females led to the results in Table 6 where $\mathrm{Cd}, \mathrm{Cu}$ and $\mathrm{Zn}$ are shown to be significantly higher in females. This preferential accumulation of metals in females was reported for Choromytilus meridonalis and Mytillus edulis. ${ }^{1,6}$ Heizen and Rebello and Rezende and Drude, however, were not able to find preferential accumulation in P. perna certainly because of the smaller number of observed organisms. ${ }^{13,16}$

\section{Conclusions}

Concentrations of the studied trace metals in P. perna from the coast of Rio de Janeiro are below the recommended levels for human food, except in the case of $\mathrm{Zn}$, in some sites of Guanabara Bay, and chromium.

The absence of normal distribution for the whole set of data while normality occurs at the site level is an indication that the centre (average) of each sub-group of data (site or region) represent population responses to different environmental conditions. Both the intra -population variability and the apparent lack of proportional response to different contamination levels derived from different source strength are limiting factors to the direct use of Perna perna as biomonitor. In general, we obtained statistical significance when looking for differences between average values from sites and regions equal or higher than $30 \%$, using $\mathrm{n}=10$. In order to prove a statistically significant $(\mathrm{p} \leq 0.05)$ difference among averages that are $10-20 \%$ apart, sample size should be increased to 30-40 organisms at each sampling site. Although this increase in sample size improves the significance of the statistical analysis it does not change the fact that the difference between extreme values rarely exceeds $100 \%$, although concentration in water may be different by a factor of 4 or 5 .

As for Guanabara Bay that is heavily polluted also by organic substances, including, mussels are not anymore found nearby the main industrial sources. Domestic sewage, a diffuse source of copper, has decreased oxygen concentration in these inner areas of the bay to levels that in certain occasions may be lower than that required for aerobic life. There, particulate matter content of 30 - 50 $\mathrm{mg} \mathrm{L}^{-1}$ derived partly form soil erosion and partly form the internal primary production $\left(2 \mathrm{~g} \mathrm{C}^{-2} \mathrm{day}^{-1}\right)$, as well as the presence of anoxic sediments provide favourable conditions for fast water to sediment transfer of trace metals released from industrial point sources. ${ }^{23}$ As resulting from this melange of environmental impacts P. perna abundance became restricted to the least industrialised areas where, in addition, fresh seawater circulation is most efficient. Consequently, metal concentration in P. perna does not reflects hot spot conditions but moderated average concentrations mostly influenced by diffuse sources inputs. Moreover, the heavy sewage input and the eutrophic conditions in this enclosed estuary provide likewise abundance of organic ligands that reduce bioavailability of copper and possibly of chromium. Magalhães et al. ${ }^{32}$ showed that, due to the water organic load, 20 to $33 \%$ of chromium appears as $\mathrm{Cr}(\mathrm{III})$, a less toxic species that can be efficiently removed to sediments. In Sepetiba Bay, where there are no present indications of eutrophication, the mussel is rarely found in sites near the industrial district, possibly also due to the environmental alterations.

Extensive environmental degradation similar to that existing in Guanabara Bay are now frequently found in estuarine systems serving large urban-industrialised centres in developing countries. The use of P. perna in biomonitoring activities in these areas may be limited by some of the factors described above and will require prior to implementation profound understanding of environmental functioning as well as of source strength and distribution. Notwithstanding, P. perna seems to respond reliably to metal inputs usually derived from domestic sewage release, a major source of seawater contamination in the developing world.

\section{Acknowledgement}

The authors are grateful for the financial support received from the Brazilian Research Council, to Prof. N. Miekeley and Prof. C.L. Silveira for the ICP/MS and ICP/ AES analytical support.

\section{References}

1. Cossa, D.; Oceanol. Acta. 1989, 12, 417.

2. Programme des Nation Unies pour l'Environment; Méthodes des Référence pour les Études de la Pollution Marine, UNEP/ IOC/IAEA: Monaco, 1994.

3. Depledge, M.H.; Rainbow, P.S.; Comp. Biochem. Physiol. 1990, 97C, 1 .

4. Wang, W.; Environ. Int. 1987, 13, 437. 
5. Riget, F.; Johansen, P.; Asmund, G.; Mar. Pollut. Bull. 1996, 32,745 .

6. Orren, M.J.; Eagle, G.A.; Hennig, H.F.-K.; Green, A.; Mar. Poll. Bull. 1980, 11, 253.

7. Daskalakis, K.D.; Mar. Pollut. Bull. 1996, 32, 794.

8. Gordon, M.; Knauer, G.A.; Martin, J.H.; Mar. Pollut. Bull. 1980, 11, 195.

9. Depledge, M.H.; Ambio 1990, 19 5, 251.

10. Phillips, D.J.H.; Muttarasin, K.; Mar. Environ. Res. 1985, 15, 215.

11. Patel, B.; Anthony, K.; Mar. Biol. 1990, 108, 457.

12. Hunter, C.L.; Stephenson, M.D.; Tjeerdema, R.S.; Crosby, D.G.; Ichikawa, G.S.; Goetzl, J.D.; Paulson, K.S.; Crane, D.B.; Martin, M.; Newman, J.W.; Mar. Pollut. Bull. 1995, 381.

13. Heinzen, V.F.; Rebello, A.L.; Thalassia Jugosl. 1980, 16, 381. (text can be obtained from the authors under request).

14. Pfeiffer, W.C.; Lacerda, L.D.; Fiszman, M.; Lima, N.R.; Cien. Cult. 1985, 37, 297.

15. Lima, N.R.W.; Lacerda, L.D.; Pfeiffer, W.C.; Fiszman, M.; Environ. Technol. Lett. 1986, 7, 453.

16. Rezende, C.E.; Lacerda, L.D.; Rev. Brasil. Biol. 1986, 46 , 239.

17. Kurita, M.H.; Pfeiffer, W.C.; International Conference on Heavy Metals in the Environment, Edinburg, UK, 1991.

18. Carvalho, C.E.V.; Lacerda, L.D.; Gomes, M.P.; Acta Limnol. Bras. 1993, VI, 222.

19. Empresa de Pesquisa Agropecuária e Difusão de Tecnologia de Santa Catarina S.A. - Gerência de Agricultura e Pesca; Manual de Cultivo do Mexilhão Perna perna, GAPES: Florianópolis, 1994. (text can be obtained from the authors under request).
20. Salomão, L.C.; Bol. Fisiol. Animal 1980, 4, 143.

21. Diniz, A.G.; Hamacher, C.; Wagener, A.L.R.; GonzalezRodriguez, E.; J. Braz. Chem. Soc. 2003, 14, 815.

22. Wagener, A. de L. R., Anais do II Simpósio de Ecossistemas da Região Costeira Sul-Sudeste Brasileira, Academia de Ciência de São Paulo: São Paulo, 1991.

23. Rebello, A.L.; Haekel, W.; Moreira, I. Santelli, R.; Schroeder, F.; Mar. Chem. 1986, 18, 215.

24. Coimbra, J.; Carraça, S.; Comp. Biochem. Physiol. 1990, 95C, 265.

25. Depledge, M.H.; Bjerregaard, P. In Phenotypic Response and Individuality in Aquatic Ectotherms, Aldrich, J.C, ed.; Japaga: Wicklow, 1989.

26. Alevato, S.J.; Rebello, A.L.; Talanta 1981, 28, 909.

27. Karez, C.S.; Amado-Filho, G.M.; Moll, D.M.; Pfeiffer, W.C.; An. Acad. Bras. Cien. 1994, 66, 205.

28. Japan International Cooperation Agency; The Study on Recuperation of the Guanabara Bay Ecossystem, Kokusai Kogyoco Ltda: Tokyo, 1994. (text can be obtained from the authors under request).

29. Van den Berg; Rebello, A.L.; Sci.Total Environ. 1986, $58,37$.

30. Rebello, A.L.; Ponciano, C.; Melges, L.H.; An. Acad. Bras. Cien. 1988, 60, 419.

31. Rebello-Wagener, A.L.; Bouch, C.; Melges, L.H.; Wagener, K.; Carreira,R.; Chem. Ecol. 1992, 6, 19.

32. Magalhães, E., Farias, P, Wagener, A.L.R.; Croatia Chem. Acta. 1997, 70, 259.

Received: September 9, 2003 Published on the web: February 3, 2004 